\title{
RADIOCARBON RESERVOIR AGES AND HARDWATER EFFECT FOR THE NORTHEASTERN COASTAL WATERS OF ARGENTINA
}

\author{
Eduardo A Gómez ${ }^{1}$ C Marcela Borel ${ }^{2}$ - Marina L Aguirre ${ }^{3}$ - Daniel E Martínez ${ }^{4}$
}

\begin{abstract}
Accelerator mass spectrometry (AMS) radiocarbon dates were obtained for 18 mollusk shells collected alive along the Buenos Aires province coast, Argentina, over the period AD 1914-1935. Reservoir ages were estimated for all samples on the basis of the tree-ring calibration curve for the Southern Hemisphere (SHCal04, McCormac et al. 2004) and the marine $\Delta R$ values calculated as the difference between the conventional ${ }^{14} \mathrm{C}$ age and the age deduced from the marine, mixedlayer model calculation (Marine04, Hughen et al. 2004). For most coastal locations, a great $\Delta \mathrm{R}$ scatter was observed, ranging from 191 to $2482 \mathrm{yr}$, which is explained by the input of varying content of dissolved carbonate by rivers and groundwater ("hardwater effect") and indicates a serious limitation for shell-based ${ }^{14} \mathrm{C}$ chronologies. Within the interior of Bahía Blanca estuary, $\Delta R$ values ranged from -40 to $50 \pm 46$ as a consequence of the local geological particularities of the environment. This suggests that, with some restrictions, the marine calibration curve with standard parameters $(\Delta R=0)$ could be used at this location.
\end{abstract}

\section{INTRODUCTION}

When the radiocarbon activity of the reservoir or source from which the organisms obtain their carbon differs from the atmosphere, even after the normalization for isotopic fractionation, it is necessary to perform an additional correction of the conventional ${ }^{14} \mathrm{C}$ age to calibrate it to sidereal years. The oceanic reservoir exchanges $\mathrm{CO}_{2}$ with the atmospheric reservoir and the ocean surface concentration of ${ }^{14} \mathrm{C}$ at any given point in time and place depends on the ${ }^{14} \mathrm{C}$ concentration of surface air $\left(\mathrm{CO}_{2}\right)$ mixed into the seawater by wave action and precipitation. The equilibrium between the ${ }^{14} \mathrm{C}$ incorporation rate from the atmosphere and its decay time in the oceans leads to an offset between both reservoirs evidenced by an apparent aging of several hundred years of the ocean surface-mixing layer. Moreover, this offset between reservoirs can be largely modified by the incorporation of a different carbon $(\mathrm{C})$ isotopic composition by ocean circulation and/or local terrestrial inputs to the surface-mixing layer.

Since marine organisms obtain their $\mathrm{C}$ from the surrounding seawater where they live, biogenic marine samples like molluskan shells generally exhibit ${ }^{14} \mathrm{C}$ ages several hundred years older than their contemporaneous atmospheric counterparts. Stuiver et al. (1986) define the reservoir age $R$ as the difference between the conventional ${ }^{14} \mathrm{C}$ ages of samples grown contemporaneously in the atmosphere and in the marine reservoir. The regional difference from the average global marine reservoir correction is designated $\Delta \mathrm{R}$ (Stuiver and Braziunas 1993), and as a first approximation, $\Delta \mathrm{R}$ values for each region are assumed to be constant. However, ocean circulation patterns in some regions may have altered $\Delta \mathrm{R}$ values in both long- and short-term timescales (Reimer and Reimer 2001).

Comparisons of ${ }^{14} \mathrm{C}$-based chronologies between different locations and samples from differing reservoirs need a conversion of conventional ${ }^{14} \mathrm{C}$ ages into calibrated ages. However, as marine regional differences $(\Delta R)$ can be very large (e.g. $885 \pm 45^{14} \mathrm{C}$ yr in the Ross Sea, Antarctic Ocean, Stuiver et al. 1986), knowing the regional $\Delta \mathrm{R}$ first and consequently subtracting it from the ${ }^{14} \mathrm{C}$

\footnotetext{
${ }^{1}$ Instituto Argentino de Oceanografía (CONICET-UNS), Camino "La Carrindanga" km 7, CC 804, 8000 Bahía Blanca, Argentina. Also: UTN Facultad Regional Bahía Blanca, 11 de Abril 461, 8000 Bahía Blanca, Argentina. Corresponding author. Email: gmgomez@criba.edu.ar.

${ }^{2}$ CONICET, Departamento de Geología, Universidad Nacional del Sur. San Juan 670, 8000 Bahía Blanca, Argentina.

${ }^{3}$ INGEA CONICET, Laboratorio 6 (Malacofauna Cuaternaria), Facultad de Ciencias Naturales y Museo, Calle 64 no. 3 (119 y 120), 1900 La Plata, Argentina.

${ }^{4}$ CONICET-Centro de Geología de Costas y del Cuaternario, Universidad Nacional de Mar del Plata, CC 722, 7600 Mar del Plata, Argentina.
} 
marine ages is essential to convert the conventional ages into calibrated ages. For a given region, $R$ can be determined from paired contemporaneous marine and terrestrial samples, or by measuring the ${ }^{14} \mathrm{C}$ age of marine samples collected prior to the stratospheric artificial ${ }^{14} \mathrm{C}$ injection that occurred in the late 1950 s and early 1960 s by atmospheric nuclear detonations.

Despite its importance, little reservoir correction data are available for the eastern coast of South America. The only available data are from the southern and southeastern Brazilian marine shallow coastal waters of Paraná and Santa Catarina states (Eastoe et al. 2002; Angulo et al. 2005). The data yield a regional $R$ of $408 \pm 18{ }^{14} \mathrm{C}$ yr with an averaged $\Delta \mathrm{R}$ value as small as $8 \pm 17^{14} \mathrm{C}$ yr for the mid20th century.

Measurements of regional $\Delta \mathrm{R}$ based on pre-bomb shells are currently not available for the extensive Atlantic coast of Argentina. For this reason, Guilderson et al. (2000) applied an $R$ value of $600{ }^{14} \mathrm{C}$ $\mathrm{yr}$ as determined by Broecker and Olson (1961) for the Falkland current in order to correct the ${ }^{14} \mathrm{C}$ age of fossil shells from the Argentine shelf, a value similar to the one Albero et al. (1987) obtained $\left(630{ }^{14} \mathrm{C}\right.$ yr) by comparing paired continental-marine samples from the Beagle Channel, south of Tierra del Fuego. However, these values must be taken as approximations because on the Atlantic coastal areas they are most likely locally modified.

Based on pairs of modern bivalve shells and grasses collected alive from different coastal localities in Patagonia and Tierra del Fuego, Cordero et al. (2003) estimated modern local $R$ values for the Atlantic coast ranging from 80 to $1100{ }^{14} \mathrm{C} \mathrm{yr} \mathrm{BP}$. However, due to the differences between the atmospheric and marine reservoirs, these paired samples would exhibit a differing and unknown impact of the ${ }^{14} \mathrm{C}$ increment caused by the atmospheric nuclear bomb testing. This fact makes it difficult, if not impossible, to use these $R$ values to correct Holocene ${ }^{14} \mathrm{C}$ dates.

Despite the absence of regional $\Delta \mathrm{R}$ corrections for the Buenos Aires province coast, there are numerous investigations of Holocene sea-level fluctuations and paleoenvironmental changes based on a ${ }^{14} \mathrm{C}$ chronology obtained from ${ }^{14} \mathrm{C}$ dates of coastal marine molluskan (bivalves and gastropods) shell samples. Most of these chronologies were performed on the same molluskan taxa analyzed here. They are benthic and typically shallow-water species living in a relatively restricted water depth range and are very abundant in fossiliferous concentrations (shell ridges and tidal flat facies) along the Bonaerensian coastal area. However, as local reservoir corrections have not been applied, most of these studies offer shell-based ${ }^{14} \mathrm{C}$ chronologies that remain uncalibrated, preventing correlations with other localities from Argentina and elsewhere around the world.

It should be pointed out that due to the predominant western winds with respect to the alignment of the coast and to the extensive continental shelf, the local input of old marine $C$ by deep-water upwelling to the coastal areas analyzed here can be discarded. However, as the taxa analyzed are euryhaline and tolerate a wide salinity range, they are likely to reflect local continental $\mathrm{C}$ inputs that might strongly modify the pure marine reservoir effect.

Using ${ }^{14} \mathrm{C}$ accelerator mass spectrometry (AMS) measurements performed on marine mollusk shells collected between AD 1914 and 1935, this paper reports the first $\Delta \mathrm{R}$ values for the Argentinean Atlantic surface coastal waters. A high variability in the $\Delta \mathrm{R}$ of some locations is acknowledged and its origin and implications on determining Holocene shell-based chronologies are discussed.

\section{METHODS}

Eighteen shell samples of known ages from the southern and southeastern coast of Buenos Aires province, Argentina, SW Atlantic Ocean, were selected to determine their $R$ by ${ }^{14} \mathrm{C}$ dating. The 
shells were collected alive before atmospheric nuclear testing and were housed at the División Invertebrados, Museo Argentino de Ciencias Naturales "Bernardino Rivadavia" in Buenos Aires, which houses the most important invertebrate collection in Argentina. Collection sites and dates of collection are reported in Figure 1 and Table 1.

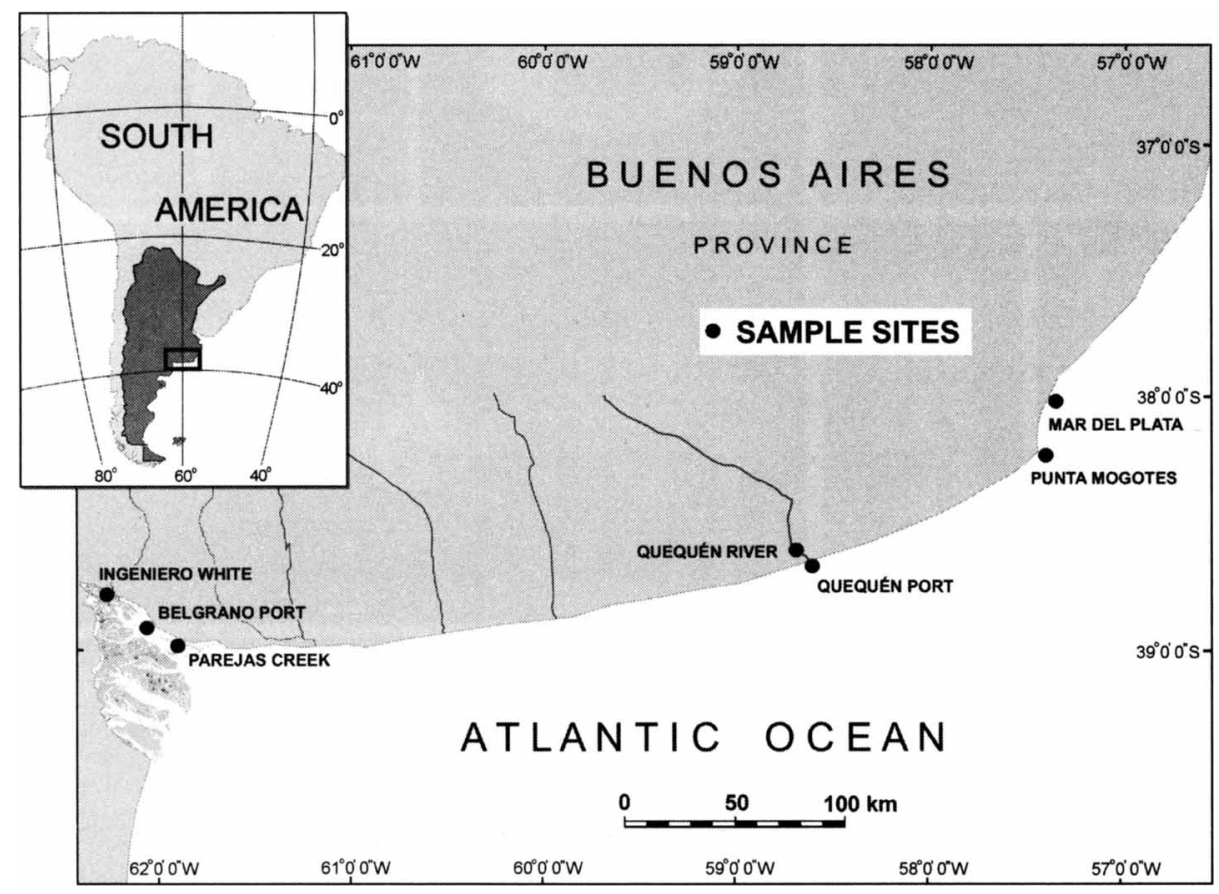

Figure 1 Location of samples collected on the southern and southeastern coasts of Buenos Aires province, Argentina.

Although the collection sites are associated with localities and/or geographical features with defined coordinate sets (Table 1), precise sampling locations for individual samples are unavailable within the Quequén River and Mar del Plata collection sites.

Determination of $R$ values for samples from collections is problematic at times as there is usually no documentation indicating whether the samples were collected alive or not. In this case, however, the mollusk samples employed here were obviously collected alive in order to represent their natural habitat as they were used for further investigations. In order to eliminate or reduce the uncertainty linked to the unlikely event that death and collection dates did not coincide, only those shells without any evidence of abrasion or fading, with an intact periostracum, and which retained their original color and brightness were chosen to perform the AMS datings (Figure 2).

Seventeen bivalve samples (Pitar rostratus and Brachidontes rodriguezii from Bahía Blanca estuary, Mactra marplatensis and Tagelus plebeius from Quequén Grande River estuary, Mactra patagonica from Punta Mogotes, and Mactra isabelleana and Mactra patagonica from Mar del Plata) and 1 gastropod sample (Littoridina australis from Bahía Blanca estuary) collected between AD 1914 and $\mathrm{AD} 1935$ along the coast of Buenos Aires province were dated. ${ }^{14} \mathrm{C}$ analyses were performed for AMS dating at the Beta Analytic Radiocarbon Dating Laboratory (Miami, Florida, USA) following the standard pretreatment protocol for shells: washing in deionized water first to remove associated 


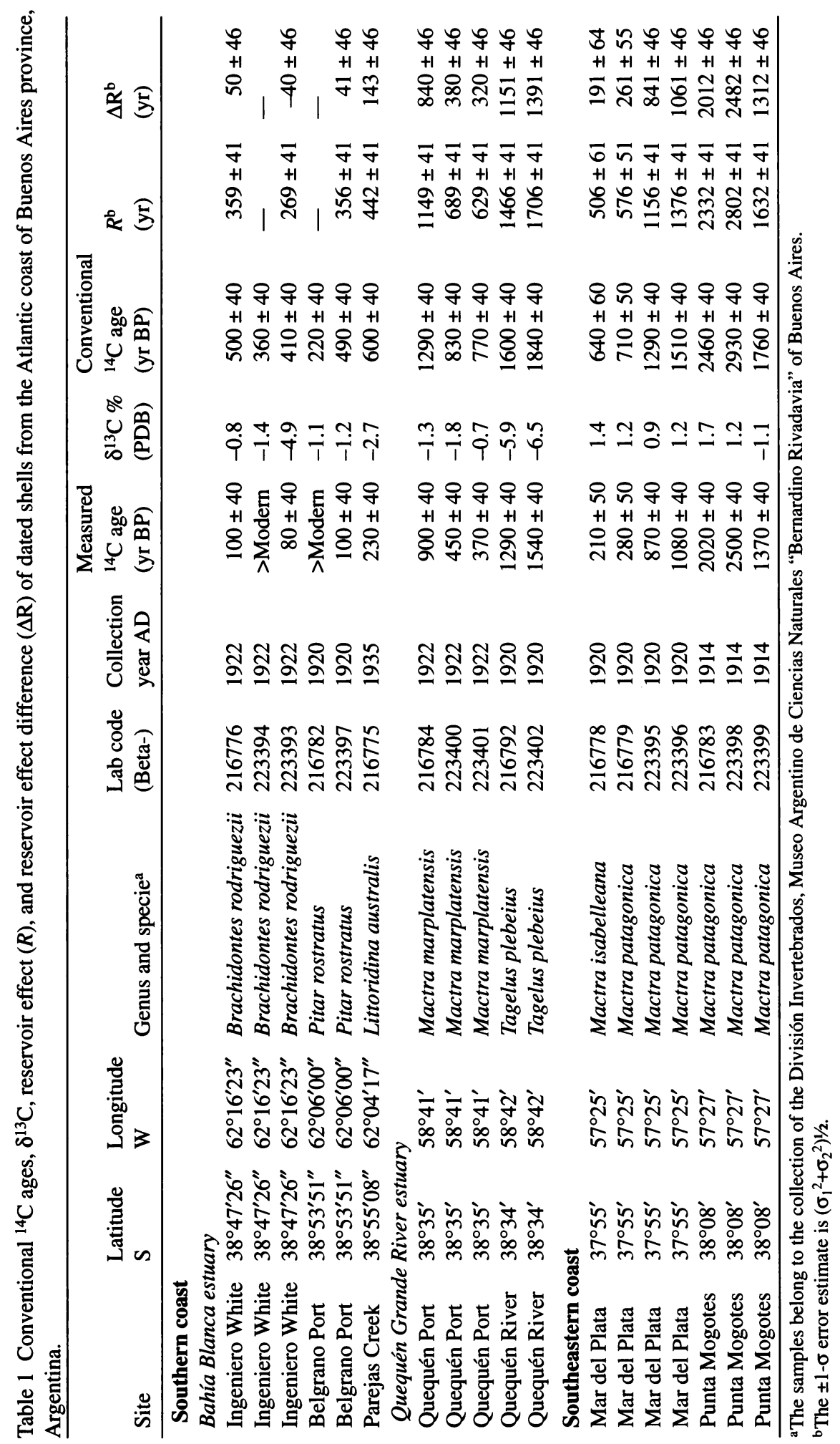



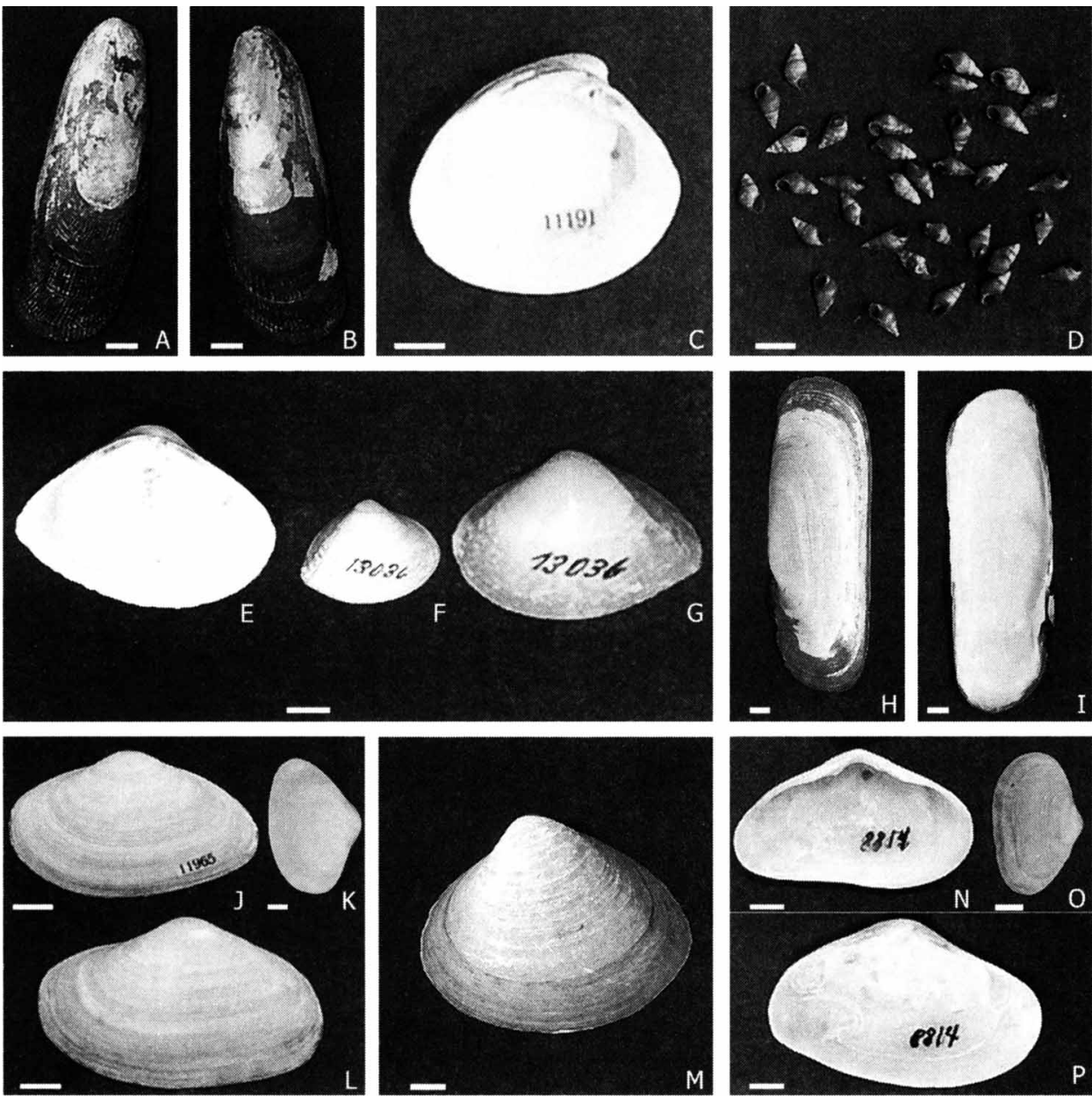

Figure 2 Dated shell specimens: A-B. Brachidontes rodrigue-ii (d`Orb.), exterior view, the dark parts are preserved periostracum; C. Pitar rostratus (Koch), interior view; D. Shells of Littoridina australis (d'Orb.) from Arroyo Parejas; E-G. Mactra marplatensis (Doello-Jurado); E. Interior view; F-G. Exterior views: H-I. Tagelus plebeius (Light.); H. Exterior view of valve with intact periostracum. I. Interior view: J-L Mactra patagonica (d'Orb.) from Mar del Plata site, J. Exterior view, K. Interior view. L. Exterior view; M. Mactra isabelleana (d’Orb.) from Mar del Plata site, exterior view; N-P. Mactra patagonica (d’Orb.) from Punta Mogotes site: N. Interior view, M. Exterior view, P. Interior view. Scale bars $=0.5 \mathrm{~cm}$ in all photographs.

organic sediments and debris and repeatedly subjected to $\mathrm{HCl}$ etches to eliminate secondary carbonate components. The surfaces of thick shells were also physically abraded prior to etching down the remaining, primary core. Conventional ${ }^{14} \mathrm{C}$ ages presented here (Table 1) are corrected for isotopic fractionation using the measured $\delta^{13} \mathrm{C}$ values and normalized to $-25 \%$ PDB (according to Stuiver and Polach 1977).

The $R$ values were calculated from the difference between the conventional ${ }^{14} \mathrm{C}$ age and the atmospheric age interpolated to the collection year from the Southern Hemisphere calibration data set (McCormac et al. 2004). $\Delta \mathrm{R}$ values were calculated from the difference between the sample conventional ${ }^{14} \mathrm{C}$ ages and those of the marine calibration data set for the surface mixed layer (Hughen et al. 2004) of the collection years. 


\section{RESULTS AND DISCUSSION}

The ${ }^{14} \mathrm{C}$ ages, $R$, and $\Delta \mathrm{R}$ values (expressed in yr $\mathrm{BP}$ ) measured in this study are given in Table 1 . Two of the 6 samples from the Bahía Blanca estuary (BETA-223394 and BETA-216782) supposedly collected in $\mathrm{AD} 1922$ show ${ }^{14} \mathrm{C}$ activity higher than modern $(>100 \mathrm{pMC})$. Although the cause of the high ${ }^{14} \mathrm{C}$ activity of these samples is unknown, they may have been collected after 1950 and the date mislabeled. For this reason, both samples were excluded from this analysis.

For the inner Bahía Blanca estuary zone, the conventional ${ }^{14} \mathrm{C}$ ages (Figure 3) of mollusk shells collected in AD 1920 on the coast of Ingeniero White (Brachidontes rodriguezii) and Belgrano Port (Pitar rostratus) show similar values to those given by the marine surface mixed layer, yielding an average $\Delta \mathrm{R}$ of $17{ }^{14} \mathrm{C}$ yr. However, the outermost sample from this estuary, Parejas Creek (Littoridina australis), exhibits a ${ }^{14} \mathrm{C}$ age of $600{ }^{14} \mathrm{C}$ yr $(\Delta \mathrm{R}=143 \mathrm{yr})$, identical to the value determined by Broecker and Olson (1961) for the Falklands current.

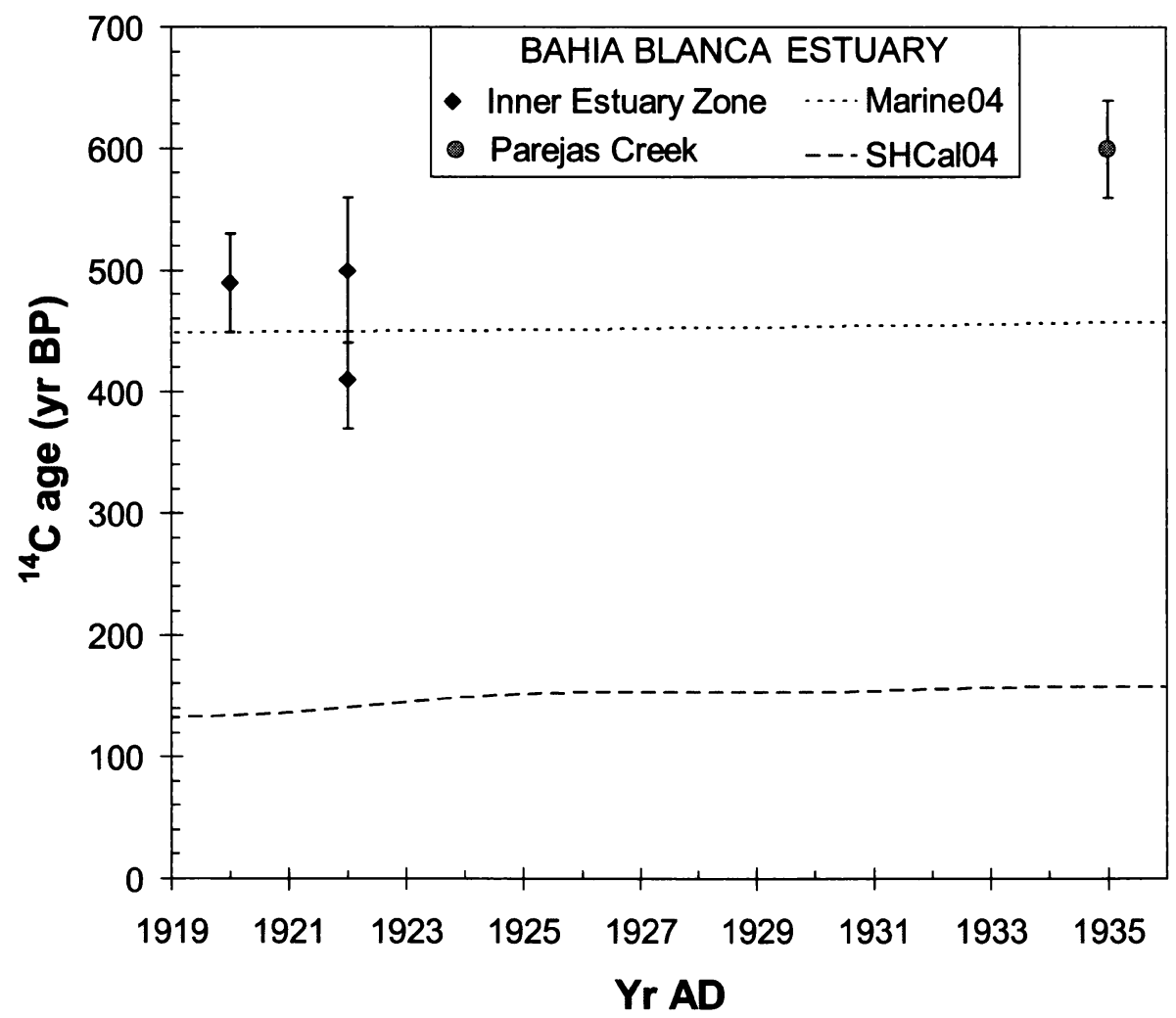

Figure 3 Conventional ${ }^{14} \mathrm{C}$ ages for the 4 shell samples from the Bahía Blanca estuary (Table 1) plotted versus year of collection. The thick dashed line shows the terrestrial calibration curve for the Southern Hemisphere (McCormac et al. 2004). The reservoir age $R$ is the difference between the measured sample age and the terrestrial calibration curve. The thin dashed line shows the marine calibration curve for $\Delta R=0$ (Hughen et al. 2004).

Overall, the results can be explained by the particular environmental setting of the Bahía Blanca estuary. The inner estuary zone has a restricted exchange with water from the open Atlantic Ocean, with an almost negligible continental water runoff. Maximum depths of the estuary channel reach 
$20 \mathrm{~m}$ and its intertidal zone represents more than $70 \%$ of the estuarine basin total area. The strong tidal currents, produced by the average 3-m tidal range of this estuary, lead to a water body of vertically homogeneous characteristics. Such hydrological and oceanographic conditions (restricted oceanic water exchange, low continental water input, low depth, and extensive surface for atmospheric exchange and strong vertical mixing) are probably responsible for the locally increased ${ }^{14} \mathrm{C}$ content in the 3 samples from the internal estuary area with respect to the continental shelf water, which according to the results of Broecker and Olson (1961) should have a smaller proportion of ${ }^{14} \mathrm{C}$.

However, Littoridina australis shells sampled in the intertidal area at the mouth of Parejas Creek (Beta-216775), a former freshwater course, yield a relatively older age $\left(600{ }^{14} \mathrm{C} \mathrm{yr}\right)$ than the inner estuary samples. The relatively increased ${ }^{14} \mathrm{C}$ age of this sample could be a consequence of the presence of carbonated sediments that crop out in the creek basin. This hypothesis is also supported by the wide salinity tolerance (1-40\%) of L. australis (Aguirre and Farinati 2000; Aguirre and Urrutia 2002; De Francesco and Isla 2003), allowing this species to easily incorporate old dissolved carbonates ("hardwater effect") from freshwater inputs.

For the Quequén Grande River estuary, the ${ }^{14} \mathrm{C}$ ages (Figure 4) of shells from AD 1920 and 1922 show noticeably greater spread than those from the Bahía Blanca estuary. The $\Delta \mathrm{R}$ estimations on Mactra marplatensis from the Quequén Port site range from 320 to $840{ }^{14} \mathrm{C} \mathrm{yr}$, while the 2 measurements of valves of different specimens of Tagelus plebeius from the Quequén River site provide a $\Delta \mathrm{R}$ of 1151 and $1391^{14} \mathrm{C} \mathrm{yr}$, respectively.

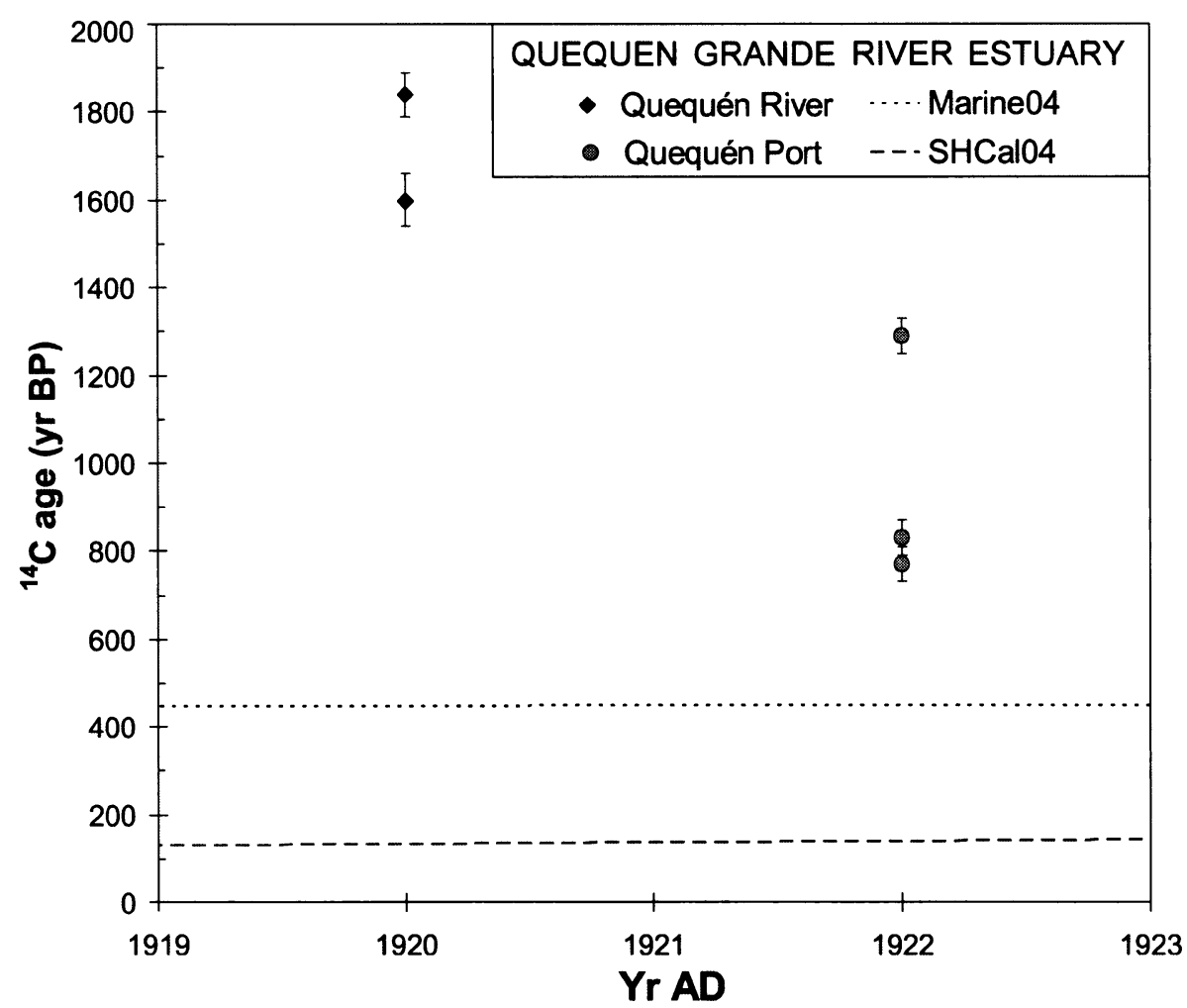

Figure 4 Conventional ${ }^{14} \mathrm{C}$ ages for the 5 shell samples from Quequén Grande River estuary (Table 1) plotted versus year of collection. 
The Quequén Grande River estuary lies on a microtidal coast (0.6-1 m tidal range) and has a mean depth of 2-3 m and a width of 150-200 m. The highest salinities are found within 2-3 km of the mouth, but approximately $15 \mathrm{~km}$ upstream the salinity is only $1 \%$. The isotopic analysis (tritium) and hydrochemical composition of the water streams at the Quequén Grande River basin indicate that the river flow is mainly composed of "old water" (Martínez et al. 2006), which in hydrologic sciences refers to the water existing in a catchment before a rainfall event (Chapman 1999), i.e. groundwater. Superficial water is mainly (up to $80 \%$ ) integrated by base flow (water supply by subsurface groundwater) and its composition as well as that from the groundwater is predominantly bicarbonated. Consequently, the high reservoir ages of these sites most likely originate from the dissolution of ancient continental carbonates introduced into the estuary by the Quequén Grande River runoff and then used by the estuarine mollusks in the synthesis of their shells. Also, the greater $\Delta R$ values of the Quequén River site with respect to those from the Quequén Port site can be directly attributed to the terrestrial input of dissolved old carbonate provided by the river. In addition, the low stable isotope compositions exhibited by the dated T. plebeius $\left(\delta^{13} \mathrm{C}=-5.9 \%\right.$ and $-6.5 \%$ o $)$ at the Quequén River site are consistent with the valves incorporating a mixture of marine and fluvial materials.

Samples from the southeastern coast exhibit an even greater ${ }^{14} \mathrm{C}$ age range (Figure 5) than those from Quequén Grande River estuary. The 4 shells from the Mar del Plata site (Mactra isabelleana and Mactra patagonica) yield $\Delta \mathrm{R}$ values ranging from 191 to $1061{ }^{14} \mathrm{C} \mathrm{yr}$, while the 3 specimens from the Punta Mogotes site (M. patagonica) range from 1312 to $2482{ }^{14} \mathrm{C}$ yr. These results were unexpected because in contrast to the environments of the Bahía Blanca and Quequén Grande estuaries discussed above, these sample shells are from an open coast in a comparatively stable marine environment without significant river discharge. However, the great variability and values of $\Delta R$ from these sites can also be explained by the input of continental waters to this coastal region, more specifically by the watershed or groundwater discharge of old bicarbonate to the inshore zone. The shells from the southeastern coast display relatively lower $\delta^{13} \mathrm{C}$ values, ranging from -1.1 to $1.7 \%$, when compared with the typical coastal marine carbonate $\left(\delta^{13} \mathrm{C}\right.$ between 1 and $4 \%$ ). As there are no river discharges in the Mar del Plata and Punta Mogotes areas, the slightly depleted ${ }^{13} \mathrm{C}$ conditions for the valves of Mactra from these sites probably reflect the localized $\mathrm{C}$ supply by groundwater to the coastal zone.

Abundant mineral calcite is found in the loessoid sediments of southeastern Buenos Aires province, either in the form of nodules (Teruggi 1957; Tricart 1973) or as continuous and massive layers usually up to $1 \mathrm{~m}$ thickness. These layers made of calcite precipitated on a silt matrix are locally called tosca, which is the regional equivalent of the term caliche. Sediments from this region constitute a poor aquifer unitary system with free direct recharge from the surface by infiltration of rain waters, discharging as superficial water courses or directly as groundwater to the sea. Several hydrogeochemical studies (e.g. Martínez and Bocanegra 2002; Massone et al. 2005) have shown that cationic exchange and the equilibrium with calcite from tosca are the main processes that determine the water composition in this type of aquifer. The dissolution of calcite in the recharging zones leads to a groundwater of bicarbonated calcareous composition, with a $\mathrm{HCO}_{3}{ }^{-}$content generally ranging between $500-700 \mathrm{mg} / \mathrm{L}$, incorporating $\mathrm{C}$ isotopes from the atmospheric $\mathrm{CO}_{2}$ as well as from the dissolution of old carbonates. Studies carried out particularly in the Mar del Plata area (Martínez and Osterrieth 1999; Martínez and Bocanegra 2002) indicate that groundwater is always equilibrated with calcite. Also, at some locations within the Quequén Grande River basin there are layers of gypsum whose dissolution promotes calcite supersaturation as a result of the common ion effect (Appelo and Postma 1993). 


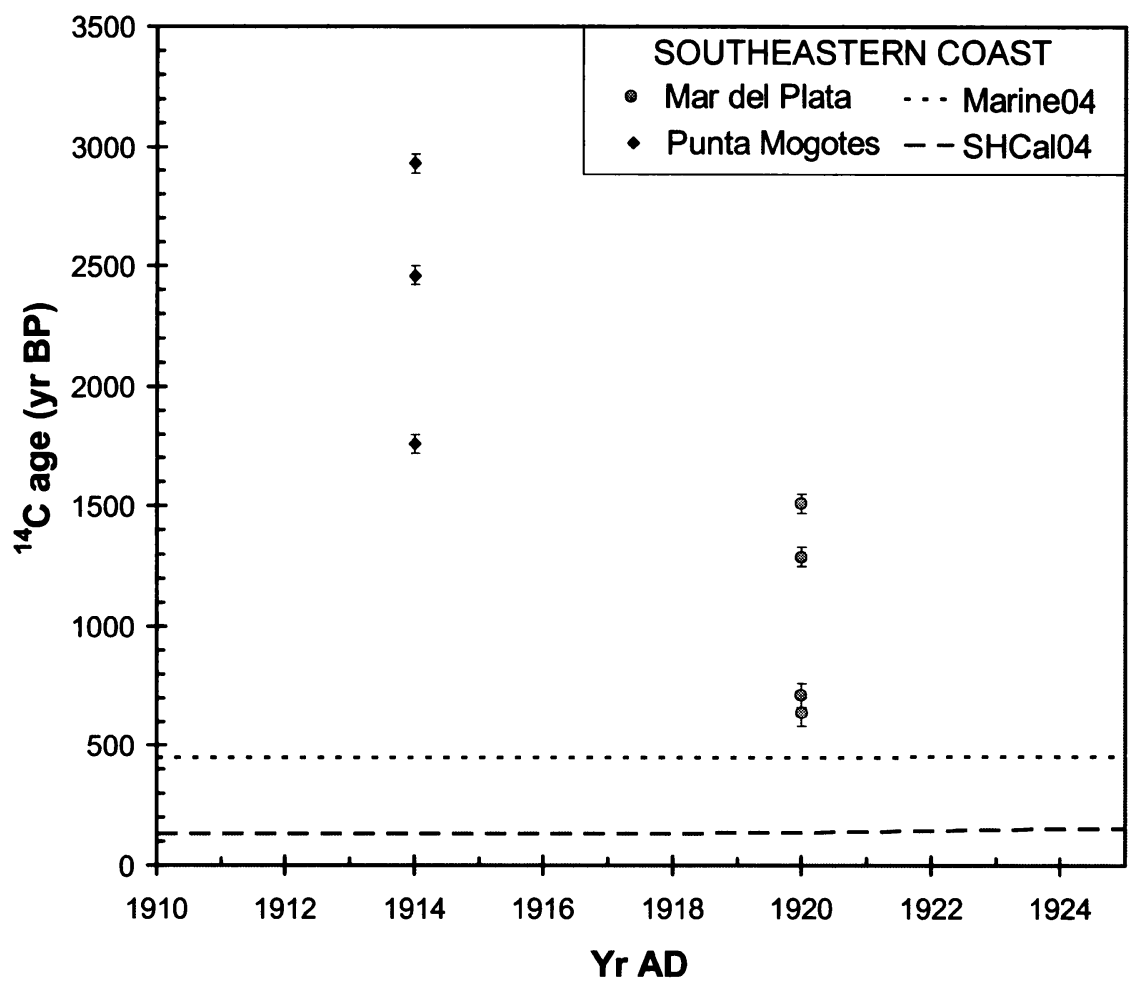

Figure 5 Conventional ${ }^{14} \mathrm{C}$ ages for the 7 shell samples from the southeastern coast (Table 1) plotted versus year of collection.

The geological carbonates widely available in the Plio-Pleistocene and Holocene deposits of the surrounding area are an important input of ${ }^{14} \mathrm{C}$-depleted carbon to the seawater and almost certainly explain the anomalous ${ }^{14} \mathrm{C}$ ages registered for the southeastern coast of Buenos Aires province. Furthermore, some recent studies (Forman and Polyak 1997; Dyke et al. 2002; Eiríksson et al. 2004) considered that the infaunal deposit-feeding habit of some mollusk taxa might explain high reservoir ages because they build their carbonate shells directly from $\mathrm{CO}_{2}$ in the ocean or from porewater in the burrowed sediment. Such an effect would contribute to the high ${ }^{14} \mathrm{C}$ ages determined in this work for shells of Tagelus plebeius and Mactra species since they are infaunal bivalves with habitats ranging from intertidal to infralittoral.

One exception seems to be the internal Bahía Blanca estuary zone, where the coastal aquifer has a slow dynamic due to the high phreatic level, the scarce hydraulic gradient, and the low permeability of the coastal sediments (Sala et al. 1985; Carrica 1998). The underground regime of this coastal area, where the direct loss by evaporation and transpiration dominates over the lateral groundwater drainage to the estuary, holds the discharge of old bicarbonate groundwater to the coast. However, it should be pointed out that as some sites of the northern inner estuary coast are closely related to local stream or creek flow, they could also be locally affected by the input of old carbonates dissolved from the vast loessoid deposits of the region, in a similar way as occurs in other coastal areas of Buenos Aires province.

The above explanation indicates that most of the Buenos Aires province coast is affected by a variable input of terrestrial dissolved old carbonates, similar to the "hardwater effect" recognized in 
other coastal sites worldwide (Little 1993; Heier-Nielsen et al. 1995; Ingram and Southon 1996; Goodfriend and Flessa 1997). The large magnitude and variability of the recent $\Delta \mathrm{R}$ determined herein and its origin, as well as the fact that current climatic and hydrological conditions have changed in the past, reveal a serious and even unbridgeable limitation for the use of Holocene shellbased ${ }^{14} \mathrm{C}$ chronologies from the coast of Buenos Aires province.

\section{SUMMARY AND CONCLUSIONS}

The AMS ${ }^{14} \mathrm{C}$ dates measured on 18 pre-bomb mollusk shells collected alive at the Buenos Aires province coast exhibit a great $\Delta \mathrm{R}$ scatter ranging from 143 to $2482 \mathrm{yr}$ for most location sites between Mar del Plata and Bahía Blanca. The large values and variability, even within the same location, are the consequence of a variable input of terrestrial dissolved old carbonates carried to the coastal area by river and groundwater discharges. By contrast, samples from the internal zone of Bahía Blanca estuary showed $\Delta R$ values ranging from -40 to $50 \pm 46 \mathrm{yr}$ as result of local geological features of the estuarine environment. These results indicate that shell-based ${ }^{14} \mathrm{C}$ chronologies in coastal areas of Buenos Aires province are seriously limited. Only within the internal zone of the Bahía Blanca estuary, and not without some restrictions, could the use of the marine calibration curve with standard parameters $(\Delta R=0)$ be justified.

\section{ACKNOWLEDGMENTS}

We would like to express our sincere thanks to Alejandro Tablado (División Invertebrados, Museo Argentino de Ciencias Naturales "Bernardino Rivadavia" of Buenos Aires) for allowing us to study mollusk samples from the museum's modern collections. This study was financially supported by the National Agency for the Promotion of Sciences and Technology of Argentina (ANPCyT), grants PICT 07-14652 and 07-14653, PICTO 07-364, PIP 5077/4 and PGI UNS 24/7H13. The clarity of this paper was significantly improved by the critical reviews of anonymous reviewers.

\section{REFERENCES}

Aguirre ML, Farinati EA. 2000. Aspectos sistemáticos, de distribución y paleoambientales de los Hydrobiidae (Littoridina spp.) (Mesogastropoda) del Cuaternario marino de Argentina (Sudamérica). Geobios 33(5): 569-97. In Spanish.

Aguirre ML, Urrutia MI. 2002. Morphological variability of Littoridina australis (d'Orbigny, 1835) (Hydrobiidae) in the Bonaerensian marine Holocene (Argentina). Palaeogeography, Palaeoclimatology, Palaeoecology 183(1-2):1-23.

Albero MC, Angiolini F, Piana EL. 1987. Holocene ${ }^{14} \mathrm{C}$ reservoir effect at Beagle Channel (Tierra del Fuego, Argentine Republic). Quaternary of South America and Antarctic Peninsula 5:59-71.

Angulo RJ, de Souza MC, Reimer PJ, Sasaoka SK. 2005. Reservoir effect of the southern and southeastern Brazilian coast. Radiocarbon 47(1):67-73.

Appelo CAJ, Postma D. 1993. Geochemistry, Groundwater and Pollution. Rotterdam: A.A. Balkema. 536 p.

Broecker WS, Olson EA. 1961. Lamont radiocarbon measurements VIII. Radiocarbon 3:176-204.

Carrica JC. 1998. Hidrogeología de la Cuenca del Arroyo Napostá Grande, provincia de Buenos Aires [unpublished $\mathrm{PhD}$ dissertation]. Bahía Blanca: Universidad
Nacional del Sur. 215 p. In Spanish.

Chapman T. 1999. A comparison of algorithms for stream flow recession and baseflow separation. Hydrological Processes 13(5):701-14.

Cordero RR, Panarello H, Lanzelotti S, Favier Dubois CM. 2003. Radiocarbon age offset between living organisms from the marine and continental reservoir in coastal localities of Patagonia (Argentina). Radiocarbon 45(1):9-15.

De Francesco CG Isla FI. 2003. Distribution and abundance of Hydrobiid snails in a mixed estuary and a coastal lagoon, Argentina. Estuaries 26(3):790-7.

Dyke AS, Andrews JT, Clark PU, England JH, Miller GH, Shaw J, Veillette JJ. 2002. The Laurentide and Innuitian ice sheets during the Last Glacial Maximum. Quaternary Science Reviews 21(1-3):9-31.

Eastoe CJ, Fish S, Fish P, Dulce Gaspar M, Long A. 2002. Reservoir corrections for marine samples from the South Atlantic coast, Santa Catarina State, Brazil. Radiocarbon 44(1):145-8.

Eiríksson J, Larsen G, Knudsen KL, Heinemeier J, Símonarson LA. 2004. Marine reservoir age variability and water mass distribution in the Iceland Sea. Quaternary Science Reviews 23(20-22):2247-68. 
Forman SL, Polyak L. 1997. Radiocarbon content of prebomb marine mollusks and variations in the ${ }^{14} \mathrm{C}$ reservoir age for coastal areas of the Barents and Kara seas, Russia. Geophysical Research Letters 24(8):885-8.

Goodfriend GA, Flessa KW. 1997. Radiocarbon reservoir ages of the Gulf of California: roles of upwelling and flow from the Colorado River. Radiocarbon 39(1):139-48.

Guilderson TP, Burckle L, Hemming S, Peltier WR. 2000. Late Pleistocene sea level variations derived from the Argentine Shelf. Geochemistry, Geophysics, Geosystems 1: doi:10.1029/2000GC000098.

Heier-Nielsen S, Heinemeier J, Nielsen HL, Rud N. 1995. Recent reservoir ages for Danish fjords and marine waters. Radiocarbon 37(3):875-82.

Hughen KA, Baillie MGL, Bard E, Beck JW, Bertrand CJH, Blackwell PG, Buck CE, Burr GS, Cutler KB, Damon PE, Edwards RL, Fairbanks RG, Friedrich M, Guilderson TP, Kromer B, McCormac G, Manning S, Bronk Ramsey C, Reimer PJ, Reimer RW, Remmele S, Southon JR, Stuiver M, Talamo S, Taylor FW, van der Plicht J, Weyhenmeyer CE. 2004. Marine04 marine radiocarbon age calibration, 0-26 cal kyr BP. Radiocarbon 46(3): 1059-86.

Ingram BL, Southon JR. 1996. Reservoir ages in eastern Pacific coastal and estuarine waters. Radiocarbon 38(3):573-82.

Little EA. 1993. Radiocarbon age calibration at archaeological sites of coastal Massachusetts and vicinity. Journal of Archaeological Science 20(4):457-71.

Martínez DE, Bocanegra E. 2002. Hydrogeochemistry and cation-exchange processes in the coastal aquifer of Mar del Plata, Argentina. Hydrogeology Journal 10(3):393-408.

Martínez DE, Dapeña C, Massone H, Panarello H, Quiroz Londoño OM, Ferrante A. 2006. Hidrogeoquímica e hidrología isotópica aplicada al estudio de la relación agua subterránea-agua superficial en grandes cuencas: la cuenca del río Quequén Grande, Buenos Aires, Argentina. In: Memorias del VIII Congreso de ALHSUD
(Asunción, Paraguay). p 57-8. In Spanish.

Martínez DE, Osterrieth M. 1999. Geoquímica de la sílice disuelta en el Acuífero Pampeano en la Vertiente Sudoriental de Tandilia. Hidrología Subterránea 13: 241-50. In Spanish.

Massone H, Martínez DE, Tomas ML. 2005. Caracterización hidroquímica superficial y subterránea de la cuenca superior del arroyo Grande (Prov. de Buenos Aires). In: II Seminario Hispano-Latinoamericano sobre Temas Actuales de la Hidrología Subterránea [proceedings]. Universidad Nacional de Río Cuarto, Argentina. p 47-56. In Spanish.

McCormac FG, Hogg AG, Blackwell PG, Buck CE, Higham TFG, Reimer PJ. 2004. SHCal04 Southern Hemisphere calibration, 0-11.0 cal kyr BP. Radiocarbon 46(3): 1087-92.

Reimer PJ, Reimer RW. 2001. A marine reservoir correction database and on-line interface. Radiocarbon 43(2A):461-3. (Supplemental material URL: http:// www.calib.org. Accessed 1 January 2007.)

Sala JM, Bonorino AG, Carrica JC. 1985. Aspectos hidroquímicos del acuífero libre en los alrededores de Ingeniero White, provincia de Buenos Aires. In: Primeras Jornadas Geológicas Bonaerenses [proceedings]. Tandil, Argentina. p 505-24. In Spanish.

Stuiver M, Braziunas TF. 1993. Modeling atmospheric ${ }^{14} \mathrm{C}$ influences and ${ }^{14} \mathrm{C}$ ages of marine samples to 10,000 BC. Radiocarbon 35(1):137-89.

Stuiver M, Polach HA. 1977. Discussion: reporting of ${ }^{14} \mathrm{C}$ data. Radiocarbon 19(3):355-63.

Stuiver M, Pearson GW, Braziunas T. 1986. Radiocarbon age calibration of marine samples back to $9000 \mathrm{cal} \mathrm{yr}$ BP. Radiocarbon 28(2B):980-1021.

Teruggi M. 1957. The nature and origin of the Argentine loess. Journal of Sedimentary Research 27(3):32232.

Tricart JLF. 1973. Geomorfología de la Pampa Deprimida. INTA, Colección Científica 12. Buenos Aires: Instituto Nacional de Tecnología Agropecuaria (INTA). 202 p. In Spanish. 